\title{
The Prevalence and Correlates of Back Pain in Adults: A Cross Sectional Study from Asir Region
}

\author{
ALI MOHAMMED AL-AHMARI, M.D.*; ABDULLAH ALI AL-QARNI, M.D.* and \\ OSSAMA MUSTAFA, M.D.**
}

The Department of Internal Medicine, KKU, Asir Region* and The Department of Family \& Community Medicine, King Khalid College of Medicine, Abha**, Saudi Arabia

\begin{abstract}
Background: Low back pain is a global health problem and it is a common form of muscluskeleton diseases. Low back pain interferes with the quality of life of the individuals, and it is a leading cause of medical consultation. Smoking, life style and physical activity had association with LBP.
\end{abstract}

Aim of the Study: To measure prevalence of back pain among adult population in Asir Region.

To assess back pain's correlation with age, gender, smoking and physical activity.

To assess influence of times per day and years of smoking on back pain.

Methods: The study is descriptive cross sectional study, it was performed during the period from April 2018 to May 2018 on adult educated population in Asir Region. A structured self-administered questionnaire was developed to investigate sociodemographics variables, smoking history, medical history and back pain history.

Results: The study included 400 participants, 260 (65\%) of them were males and $140(35 \%)$ were females. There were $52.3 \%$ of participants reported having back pain, and 97 $(24.3 \%)$ reported having continuous back pain. Several factors influenced the prevalence of back pain; it was found that being male was associated with suffering back pain $(p$-value $=$ $0.03)$. Whereas performing sport activity was associated with having no back pain $(p$-value $=0.02)$. Age had no significant correlation with back pain. The study included $217(54.3 \%)$ current smoker and 43 (10.7\%) ex-smoker. There were 89 (22.3\%) smoking 1-3 times per day and 107 (26.8\%) smoking since 4-6 years, also in this study we find a strong relation between smoking and back pain $(p$-value $=0.001)$.

Both of times of smoking per day and years of smoking positively associated with back pain $(r=+0.3, p$-value $=0.004$; $r=+0.4, p$-value $=0.03$ respectively). Persistence of back pain positively associated with years of smoking $(r=+0.2, p$-value $=$ $0.02)$.

Conclusion: There was moderate prevalence of back pain among our participants. The prevalence of back pain was found to be associated with gender, smoking state and physical

Correspondence to: Dr. Ali Mohammed Al-Ahmari,

The Department of Internal Medicine, KKU, Asir Region, Saudi Arabia activity. It was more prevalent in males and smokers, whereas performing sport activity was associated with having no back pain. The prevalence of back pain was found to be associated with times and years of smoking and the chronic back pain was positively associated with years of smoking.

Key Words: Lower back pain - Gender - Smoking - Saudi Arabia-Adults.

\section{Introduction}

LOW Back Pain (LBP) is a global health problem and it is a common form of muscluskeleton diseases [1]. It is a muscle tension or pain above the inferior gluteal and below the costal margin, either with or without leg pain [2]. LBP interferes with the quality of life and it is a leading cause of medical consultation [3]. LBP is very common condition, where half of adult individuals experience LBP which can last for more than 24 hours during the year [4]. The prevalence of LBP in USA was found to be more than $60 \%$ among general population [5]. In Canada LBP was estimated to be prevalent in $84 \%$ of adults [6] and the average prevalence in Finland, Denmark and UK was $75 \%, 70 \%$ and $59 \%$ respectively [7-9]. In Saudi Arabia, the prevalence was $23.8 \%$ among population in Arar City with more prevalence among females, also this study concluded that age had no significant influence on the prevalence of back pain [12]. Physical activity was one of several factors investigated to reduce back pain [10]

Smoking is a great global public health threats that has been encountered as WHO mentioned [11] . In 2015, it was estimated that there were over one billion individuals were tobacco smokers [12] and $80 \%$ of all smokers in the world are living in less developed countries [11]. Saudi Arabia was in the 8 th rank in the world regarding tobacco use as reported by WHO [13]. A study performed in KSA 
in 2013 showed that the overall prevalence of current smoking was $12.2 \%$ and it was more prevalent in males than females [14]. Smoking causes death for many smokers [15], it also results in many disease involving; chronic obstructive pulmonary disease, lung and heart diseases, cancer and stroke [16]. It was reported that smoking, life style had association with LBP, the influence of smoking on the vertebral column was explained as smoking results in reduction of bone mineral density leading to osteoporosis and hence micro fractures appear in the vertebral column which in turn leads to degenerative changes [17].

This study reported that the prevalence of LBP was increased in smokers than former smokers and non-smokers [8]

A study concluded greater exposure to nicotine increases the amount of pain perception [18]. In the present study we aimed to measure prevalence of back pain and its correlations with age, gender, and physical activity and smoking. And assess influence of times per day and years of smoking on back pain.

\section{Subjects and Methods}

\section{Subjects and study design:}

This study is descriptive cross sectional study, it was conducted on adult educated population in Asir Region during the period from April 2018 to May 2018. The inclusion criteria were educated population who were at least middle school graduated to be able to read and understand questionnaire paper, and those who were over the age of 20 years [29]. And settled in Asir Region. Exclusion criteria were uneducated population, under the age of 20 years, and who were visitors to Asir Region. Data of 404 participants were collected, 4 of them were excluded as the data weren't complete and 400 individuals were included. Ethical approval was taken from Ethical Committee. Confidentiality and privacy will be guaranteed for all participants.

\section{Questionnaire:}

A structured self-administered questionnaire was developed and includes the following sections: Sociodemographic variables questions include; age, gender, marital status, nationality, occupation and education level. The second part included smoking history and the third part included medical history and back pain history. The questionnaire was distributed in malls, traditional markets and gardens.

\section{Statistical analysis:}

Statistical Package for Social Sciences (SPSS) software Version 21 was used for data entry and analysis. Categorical variables were expressed as percentages, the $t$-test was used for continuous variables and Chi-square test was used to test the associations which is shown in aims of this study. Tables and possible graphs were used to show the results.

\section{Results}

The present study included 400 participants, $260(65 \%)$ of them were males and 140 (3 5\%) were females. There were $112(28 \%)$ individuals in the age range of 20-29 years old, $75(18.7 \%)$ in the age range of $30-39,158(39.5 \%)$ and $55(13.8 \%)$ in the age range of 40-49 years and 50 years and more respectively. The large majority $346(86.5 \%)$ were Saudi individuals, whereas $54(13.5 \%)$ were non-Saudi. Half of participants were married and $188(47 \%)$ were singles, while $8(2 \%)$ and $4(1 \%)$ were divorced and widowers respectively. Regarding education level, individuals with university education were the dominant group $262(65.5 \%)$, followed by those with high school $100(25 \%)$ and then those having preparatory education $38(9.5 \%)$. There were $279(69.7 \%)$ reported that they had work and $121(30.3 \%)$ reported that they weren't working, (Table 1) summarizes the demographics of participants.

Table (1): Demographics of participants.

\begin{tabular}{ll}
\hline Demographics & $\mathrm{N}(\%)$ \\
\hline Age: & $112(28)$ \\
$20-29$ & $75(18.7)$ \\
$30-39$ & $158(39.5)$ \\
$40-49$ & $55(13.8)$ \\
50 & \\
Gender: & $260(65)$ \\
Male & $140(35)$ \\
Female & \\
Nationality: & $346(86.5)$ \\
Saudi & $54(13.5)$ \\
Non-Saudi & \\
Marital status: & $188(47)$ \\
Single & $200(50)$ \\
Married & $8 \quad(2)$ \\
Divorced & 4 \\
Widower & \\
Education level: & $38(9.5)$ \\
Preparatory & $100(25)$ \\
High school & $262(65.5)$ \\
University & \\
Occupation: & $279(69.7)$ \\
Yes & $121(30.3)$ \\
No &
\end{tabular}


Regarding smoking status, there were 217 $(54.3 \%)$ were smokers, $43(10.7 \%)$ were ex-smokers and $140(35 \%)$ weren't smokers. Of those who smoke, $158(39.5 \%)$ reported smoking cigarettes, $26(6.5 \%)$ reported shisha, $4(1), 20(5 \%)$ and 9 $(2.3 \%)$ reported pipe, cigar and electric cigarettes respectively. There were $49(12.3 \%)$ reported smoking more than 6 times per day and $70(17.5 \%)$ reported smoking since 6 years, the status and history of smoking are shown in (Table 2).

Table (2): Status and history of smoking.

\begin{tabular}{|c|c|}
\hline Smoking status & N (\%) \\
\hline \multicolumn{2}{|c|}{ Are you current smoker? } \\
\hline Yes & $217(54.3)$ \\
\hline No & $140(35)$ \\
\hline Ex-smoker & $43 \quad(10.7)$ \\
\hline \multicolumn{2}{|l|}{ What do you smoke? } \\
\hline Cigarettes & $158(39.5)$ \\
\hline Shisha & $26 \quad(6.5)$ \\
\hline Pipe & $4 \quad(1)$ \\
\hline Cigar & $20 \quad(5)$ \\
\hline Electric cigarettes & $9 \quad(2.3)$ \\
\hline \multicolumn{2}{|c|}{ How many times you smoke per day? } \\
\hline 1-3 times & $89(22.3)$ \\
\hline $4-6$ times & $79(19.7)$ \\
\hline More than 6 times & $49(12.3)$ \\
\hline \multicolumn{2}{|c|}{ Since when you smoke? } \\
\hline 1-3 years & $40 \quad(10)$ \\
\hline $4-6$ years & $107(26.8)$ \\
\hline More than 6 years & $70 \quad(17.5)$ \\
\hline
\end{tabular}

The medical history of participants is shown in (Table 3), there were $312(78 \%)$ of our participants reported medical problems, $209(52.3 \%)$ of them reported suffering back pain and the most reported cause of back pain was unknown reason $80(20 \%)$. The prevalence of back pain and its causes are shown in Figs. $(1,2)$ respectively. Most of patients with back pain 97 (24.3\%) reported having continues pain, while $54(13.5 \%)$ and 58 $(14.5 \%)$ reported having back pain more than and less than 3 months respectively. Regarding performing exercise, 141 (35.3\%) only reported performing exercise and the most performed was walking $101(25.3 \%)$.

The correlations between having back pain and different factors were investigated (Table 4), it was found that being male and current smoker were associated with suffering back pain ( $p$-value $=$ $0.03,0.001$ respectively), whereas performing sport activity was associated with having no back pain $(p$-value $=0.02)$. Age had no significant correlation with back pain.

\begin{tabular}{ll}
\hline Table (3): Clinical history of participants. \\
\hline Clinical history & $\mathrm{N}(\%)$ \\
\hline Having medical problems? & $312(78)$ \\
$\quad$ Yes & $88(22)$ \\
No & \\
How long did you experience back pain? & $97(24.3)$ \\
Continuously & $54(13.5)$ \\
More than 3 months & $58(14.5)$ \\
Less than 3 months & \\
Do you do any sports activity? & $141(35.3)$ \\
Yes & $259(64.7)$ \\
No & \\
What kind of sports activity do you practice? & $101(25.3)$ \\
Walking & $19(4.7)$ \\
Aerobics & $21(5.3)$ \\
Running & \\
\hline
\end{tabular}
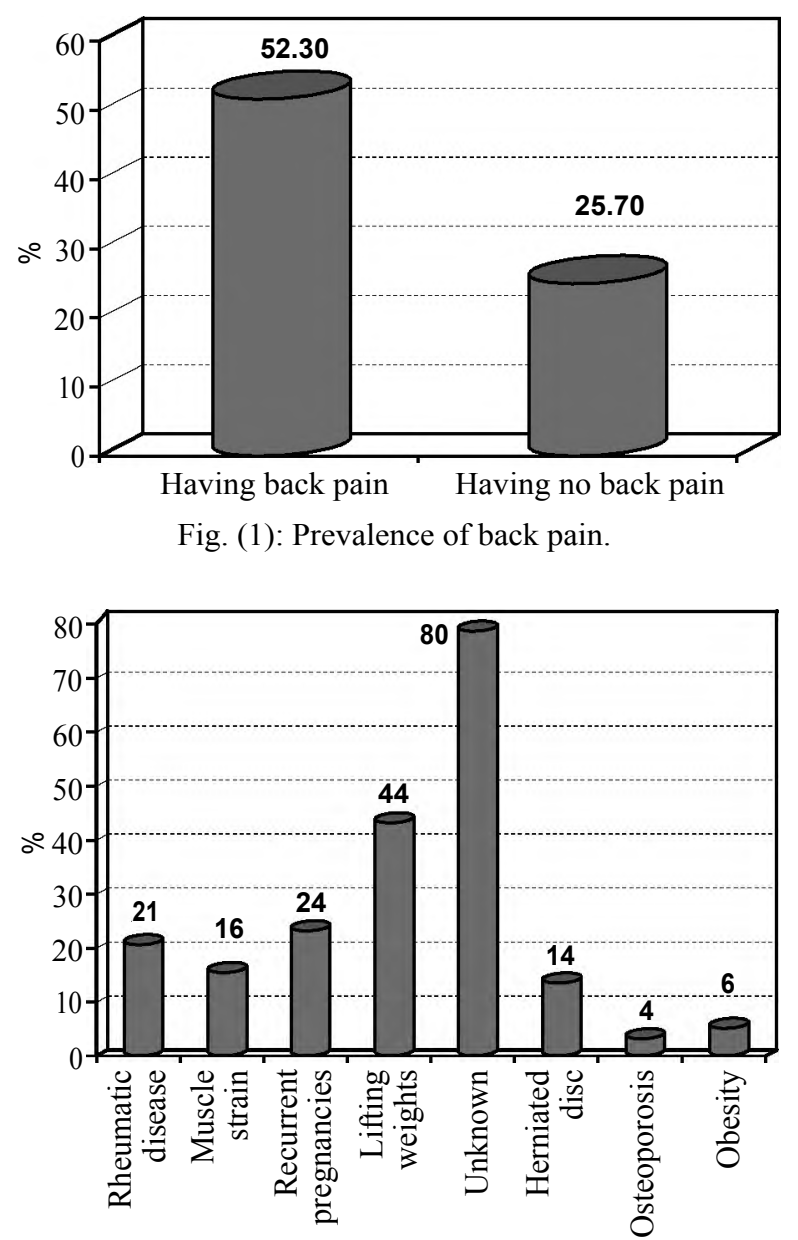

Fig. (2): Causes of back pain as reported by participants.

There was a positive significant correlation between back pain and each of smoking per day $(r=+0.3, p$-value $=0.004)$ and years of smoking $(r=+0.4, p$-value $=0.03)$, also there was a positive correlation between period of experience of back pain and years of smoking $(r=+0.2, p$-value $=0.02)$. 
Table (4): Correlations between different factors with having back pain.

\begin{tabular}{|c|c|c|c|}
\hline \multirow{2}{*}{ Variables } & \multicolumn{2}{|c|}{ Back pain $\mathrm{N}(\%)$} & \multirow{2}{*}{$\begin{array}{c}p- \\
\text { value }\end{array}$} \\
\hline & Yes (209) & No (191) & \\
\hline \multicolumn{4}{|l|}{ Age: } \\
\hline $20-29$ & $50(12.5 \%)$ & $62(15.5 \%)$ & 0.09 \\
\hline $30-39$ & $35(8.7 \%)$ & $40(10 \%)$ & \\
\hline $40-49$ & $89(22.3 \%)$ & $69(17.3 \%)$ & \\
\hline 50 & $35(8.7 \%)$ & $20(5 \%)$ & \\
\hline \multicolumn{4}{|l|}{ Gender: } \\
\hline Male & $200(50 \%)$ & $60 \quad(15 \%)$ & 0.03 \\
\hline Female & $9 \quad(2.3 \%)$ & $131(32.7 \%)$ & \\
\hline \multirow{2}{*}{\multicolumn{4}{|c|}{$\begin{array}{l}\text { Are you current } \\
\text { smoker? }\end{array}$}} \\
\hline & & & \\
\hline Yes & $173(43.3 \%)$ & $44 \quad(11 \%)$ & 0.001 \\
\hline No & $6 \quad(1.5 \%)$ & $134(33.5 \%)$ & \\
\hline Ex-smoker & $30 \quad(7.5 \%)$ & $13 \quad(3.2 \%)$ & \\
\hline \multicolumn{4}{|l|}{ Do you do any } \\
\hline \multicolumn{4}{|l|}{ sports activity? } \\
\hline Yes & $20(5 \%)$ & $121(30.3 \%)$ & 0.02 \\
\hline No & $189(47.2 \%)$ & $70 \quad(17.5 \%)$ & \\
\hline
\end{tabular}

\section{Discussion}

The present study included 400 participants, $65 \%$ of them were males and $35 \%$ were females, participants of age of 40-49 years old were more dominant $(39.5 \%)$ among all participants. There were $54.3 \%$ smokers and $10.7 \%$ ex-smokers. The most common type of smoking was cigarette $(39.5 \%)$ followed by shisha $(6.5 \%)$. Of smokers, there were 89 individuals reported smoking 1-3 times per day and least number 49 reported smoking more than 6 times per day. Most of smokers (107 individuals) reported smoking since 4-6 years. In a previous study in Saudi Arabia [14] it was found that the overall prevalence of current smoking was $12.2 \%$, and daily shisha smoking was the most common and it was reported by $4.3 \%$ followed by $1.4 \%$ of cigarette, cigar and shisha daily smokers. In the current study, there were $78 \%$ had medical problems, $35.3 \%$ only reported performing exercise and the most common type of exercise was walking $(25.3 \%)$. There were $52.3 \%$ of participants reported having back pain, continues back pain was the most dominant among participants $(24.3 \%)$ and the most reported cause for back pain was unknown (20\%). The prevalence of low back pain was lower in Arar City in KSA as it was among $23.8 \%$ of population $(23.8 \%)$ [2]. However, the prevalence in this study was lower than that reported from Canada (84\%) [6], Finland (75\%) [7], Denmark (70\%) [8] and UK (59\%) [9]. The present study showed that there were several factors influenced the prevalence of back pain including gender, smoking status and performing sports activity, however age had no significant impact on back pain $(p$-value $=0.09)$. Males and smoker individuals tended to suffer back pain ( $p$-value $=0.03,0.001$ respectively), whereas those who performed sports tended to suffer no back pain ( $p$-value $=0.02)$. In contrast to our results, it was reported from UK that females were suffering slightly more than males [19] and this was supported by a study from Saudi Arabia as the back pain was significantly more prevalent in females than in males ( $p$-value $=$ 0.02) [2]. In Indian study [20] it was demonstrated that the prevalence of low back pain was significantly higher in women than in men. Also, a study from Iran [21] showed that LBP was more prevalent in women than in men. However, our findings can be explained as the males were more dominant than females. Other studies [22,23] showed no tendency in prevalence in females. The same Saudi study [12] was in agreement with ours, as age had no significant influence on the prevalence of back pain $(p$-value $=0.051)$. However, previous studies $[24,25]$ found positive association between LBP and age. It was stated in a previous study [10] that physical activity was one of several factors investigated to reduce back pain and this was confirmed in our findings as those who were performing exercise were less prone to suffer back pain. The link between back pain and smoking has been reported and a dose response relationship was shown [26]. Other studies $[\mathbf{8 , 2 7 , 2 8}]$ reported that smoking is consistently associated with LBP.

A study from Iran showed that smoking was consistently associated with LBP [21]. In our study, back pain was positively associated significantly with times of smoking per day $(r=+0.3, p$-value $=$ $0.004)$ and years of smoking ( $r=+0.4, p$-value $=$ $0.03)$. Also, period of experiencing back pain was positively associated with years of smoking ( $r=$ $+0.2, p=0.02$ ). In American study [10] it was found that daily smokers had higher prevalence of back pain than lighter ones. This can be explained by the hypothesis that nicotine alters the threshold and perception for pain resulting in increase in the self reported pain [18] hence it can be concluded that greater exposure to nicotine increases the amount of pain perception. A study from India [20] showed that there was no association between smoking and low back pain.

\section{Conclusion:}

There was moderate prevalence of back pain among our participants. The prevalence of back pain was affected by gender, smoking status and physical activity. It was more prevalent in males and smokers, whereas performing sport activity 
was associated with having no back pain the prevalence of back pain was found to be associated with times and years of smoking and the chronic back pain was positively associated with years of smoking.

\section{References}

1- DEYO R.A. and WEINSTEIN J.N.: Low back pain. N. Engl. J. Med., 344 (5): 363-70, 2001.

2- ALANZI M.S., ALMUHAWWIS A., GHANNAM A., EL-FETOH A., MOHAMED N., ALSAHLI F.A., ALMALKI M.A., ALENEZI T.M., ALRUWAILI F.M., ALENEZI A.T. and ALANAZEY M.A.: Low Back Pain in Population of Arar City, Northern Saudi Arabia: An Epidemiological Study. Egyptian Journal of Hospital Medicine, Nov. 15; 69 (7), 2017.

3- EHRLICH G.E.: Low back pain. Bull. World. Health. Organ., 81: 671-6, 2003.

4- TESSA A.: Is teaching bad for your back? Teachingexpertise; http://www.teachingexpertise.com/articles/teachingbad back-598, 2010.

5- ANDERSSON G.B.: Epidemiological features of chronic low-back pain. Lancet, 354 (9178): 581-5, 1999.

6- CASSIDY J.D., CARROLL L.J. and CÔTÉ P.: The Saskatchewan health and back pain survey: The prevalence of low back pain and related disability in Saskatchewan adults," Spine, 23 (17): 1860-7, 1998.

7- HELIOVAARA M., SIEVERS K., IMPIVAARA O., et al.: Descriptive epidemiology and public health aspects of low back pain. Annals of Medicine, 21 (5): 327-33, 1989.

8- HARREBY M., KJER J., HESSELSØE G. and NEERGAARD K.: Epidemiological aspects and risk factors for low back pain in 38-yearold men and women: A 25-year prospective cohort study of 640 school children. European Spine Journal, 5 (5): 312-8, 1996.

9- WAXMAN R., TENNANT A. and HELLIWELL P.: A prospective follow-up study of low back pain in the community. Spine, 25 (16): 2085-90, 2000.

10- GREEN B.N., JOHNSON C.D., SNODGRASS J., SMITH M. and DUNN A.S.: Association between smoking and back pain in a cross-section of adult Americans. Cureus., Sep., 8 (9), 2016

11- World Health Organization. Media Centre. Tobacco: Fact sheet, 2017. Available at: http://www.who.int/mediacentre/ factsheets/fs3 3 9/en/.

12- World Health Organization. Global health observatory (GHO) data. Prevalence of tobacco smoking. Available at: http://www.who.int/ gho/tobacco/use/en/.

13- World Health Organization: Guidelines for controlling and monitoring the tobacco epidemic. Geneva: WHO. Available from: http://apps.who.int/bookorders/anglais/ detart $1 . j$ sp? codlan $=1 \& \operatorname{codcol}=15 \& \operatorname{codcch}=468,1998$.
14- MORADI-LAKEH M., EL BCHERAOUI C., TUFFAHA M., DAOUD F., AL SAEEDI M., BASULAIMAN M., MEMISH Z.A., ALMAZROA M.A., RABEEAH A.A. and MOKDAD A.H.: Tobacco consumption in the Kingdom of Saudi Arabia, 2013: Findings from a national survey. BMC Public Health, Dec., 15 (1): 611, 2015.

15- World Health Organization. WHO global report on trends in tobacco smoking 2000-2025. Available at: http://. www.who.int/tobacco/publications/ surveillance/ reportontrendstobaccosmoking/en/. Accessed on October 12, 2017.

16- Centers for Disease Control and Prevention. Smoking \& Tobacco Use. Fact Sheet. Available at: https://www.cdc. gov/tobacco/-data statistics/fact sheets/fast facts/ index.htm, 2017.

17- ZANOLI G., STROMQVIST B., JONSSON B., et al.: Pain in low-back pain. Problems in measuring outcomes in musculoskeletal disorders. Acta Orthop. Scand. Suppl., 73: 54-7, 2002.

18- BRAGE S. and BJERKEDAL T.: Musculoskeletal pain and smoking in Norway. J. Epidemiol. Community Health, 50: 166-69, 1996.

19- SIKIRU L. and SHMAILA H.: Prevalence and risk factors of low back pain among nurses in Africa: Nigerian and Ethiopian specialized hospitals survey study. East Afr. J. Public Health, 6 (1): 22-5, 2009.

20- MATHEW A.C., SAFAR R.S., ANITHADEVI T.S BANU M.S., SHANKAR S.L., RAI B.K. and CHACKO T.V.: The prevalence and correlates of low back pain in adults: A cross sectional study from Southern India. International Journal of Medicine and Public Health, 3 (4), 2013.

21- BIGLARIAN A., SEIFI B., BAKHSHI E., MOHAMMAD K., RAHGOZAR M., KARIMLOU M. and SERAHATI S.: Low back pain prevalence and associated factors in Iranian population: Findings from the national health survey. Pain research and treatment, 2012.

22- KATAZ J.N.: Lumbar disc disorder and low-back pain: Socioeconomic factor and consequences. J. Bone Joint Surgery Am., 88 (15): 21-4, 2006.

23- HARTVIGSEN D.C., BAKKETEIG L.V. and LEBOEUFYDE C.: The association between physical workload and low back pain clouded by the "healthy worker" effect: Population-based cross-sectional and 5-year prospective questionnaire study. Spine, 26: 1788-93, 2001.

24- BENER A., ALWASH R., GABER T. and LOVASZ G.: Obesity and low back pain. Collegium Antropologicum, 27 (1): 95-104, 2003.

25- OUÉDRAOGO D.D., OUÉDRAOGO V., OUÉDRAOGO L.T., et al.: Prevalence and factors associated with low back pain among hospital staff in Ouagadougou (Burkina Faso). Médecine Tropicale, 70 (3): 277-80, 2010.

26- CROFT P.R. and RIGBY A.S.: Socioeconomic infl uences on back problem in the community in Britain. J. Epidemiol. Community Health, 48: 166-70, 1994.

27- BIERING-SORENSEN F. and THOMSEN C.: Medical, social and occupational history as risk indicators for low- 
back trouble in a general population. Spine, 11 (7): 720 $5,1986$.

28- F.MÜLLER C., MONRAD T., BIERING-SØRENSEN F., DARRE E., DEIS A. and KRYGER P.: The influence of previous low back trouble, general health, and working conditions on future sick-listing because of low back trouble: A 15-year follow-up study of risk indicators for self-reported sick-listing caused by low back trouble. Spine, 24 (15): 1562-70, 1999.

29- MEUCCI R.D., FASSA A.G. and FARIA N.M.X.: Prevalence of chronic low back pain: systematic review. Rev. Saude Publica, 49, 2015.

\section{ملى إتتشار آلم الظهروالعوامل المتعلقة به فى منطقة عسير}

آهداف البحث: قياس مدى إنتشار آلم الظهر بين الآشخاص البالغين فى منطقة عسير. دراسة علاقة آلم الظهر بالعمر والجنس والتدخين والنشاط البدنى. دراسة تآثير مرات التدخين فى اليوم ومدة التدخين بالسنوات على آلم الظهر.

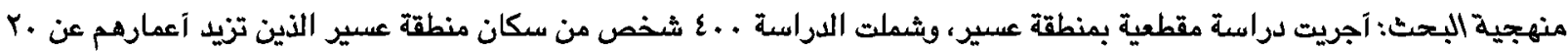

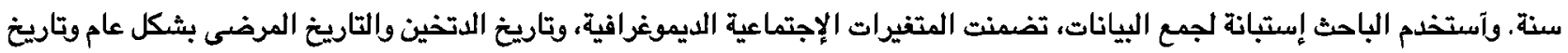
آلم الظهر بشكل خاص. وتم توزيعها بطريقة عشوائية فى الحدائق والآماكن العامة.

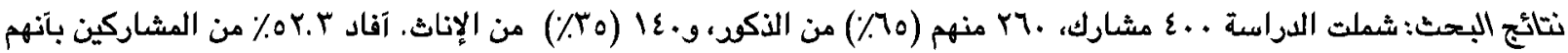

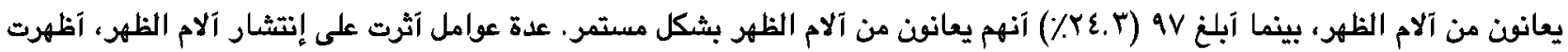

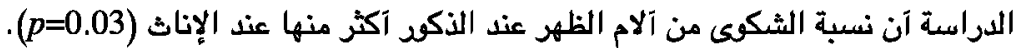

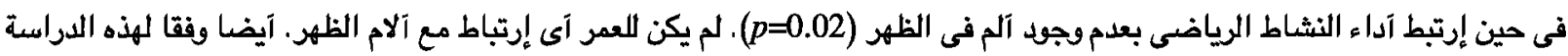

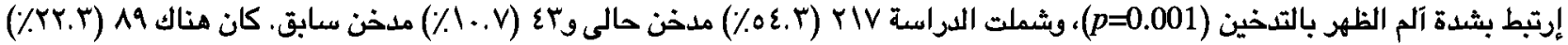

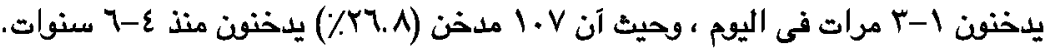

في حين الدراسة، كان آلم الظهر مرتبط بشكل إيجابى بوضوح مع مرات التخين فى اليوم الواحد (p-value=0.004, r=+0.3) وسنوات التخين (p-value=0.03,

الإستستاجات: كان هناك إنتشار متوسط لآلام الظهر بين المشاركين لدينا . آظهرت الدراسة آن إنتثار آلّ الظهر يرتبط بنوع الجنس وحالة

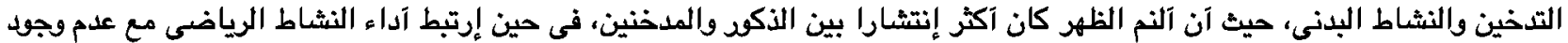

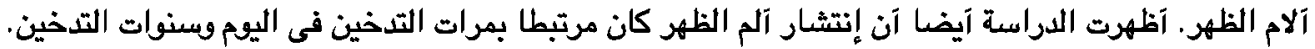

